\title{
MAJOR TECTONIC STRUCTURES IN NORTH EASTERN GREECE DEDUCED FROM GEOPHYSICAL AND SEISMOLOGICAL DATA
}

\author{
Stampolidis A. ${ }^{1}$, Tsokas G. ${ }^{1}$, Kiratzi A. ${ }^{1}$, and Pavlides S. ${ }^{2}$ \\ ${ }^{1}$ Aristotle University of Thessaloniki, School of Geology, Department of Geophysics, \\ astamp@geo.auth.gr,gtsokas@geo.auth.gr,kiratzi@geo.auth.gr \\ ${ }^{2}$ Aristotle University of Thessaloniki, School of Geology, Department of Geology, \\ pavlides@geo.auth.gr
}

\begin{abstract}
We apply lineaments analysis on the gravity and magnetic data of NE Greece, and combine seismological and geophysical data in order to delineate the major structural features. These methods are frequently used for extracting the dimensional and physical parameters of the buried structures that stimulate gravity and magnetic fields. These estimates concern the location, local depth, strike, dip and physical quantity contrast, of potential field contacts. We used results from previous studies in order to correct the Bouguer data for the gravity effect of the crust. The isostatic residual gravity anomalies, produced from the subtraction of the effect of the crust, are related to near-surface features. Noise suppression was achieved by slightly upward continuing the data by one cell size. Geologic significance of detected lineaments is confirmed by comparisons with the known geology, active tectonics and seismicity as well as with topographic lineaments.
\end{abstract}

Key words: Potential fields, depth-to-source, lineaments analysis, seismotectonics.

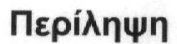

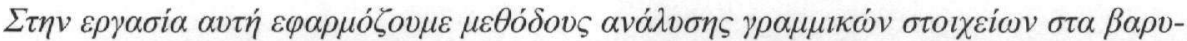

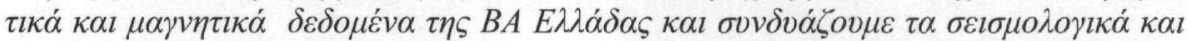

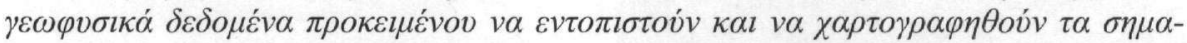

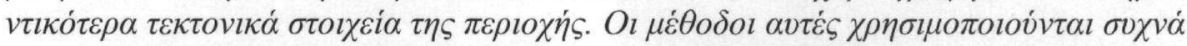

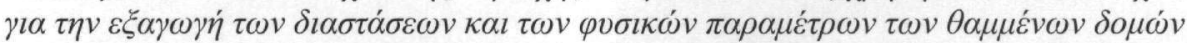

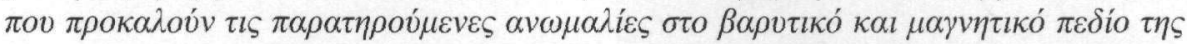

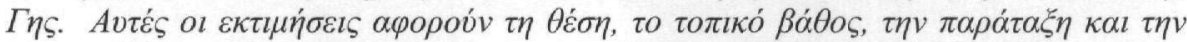

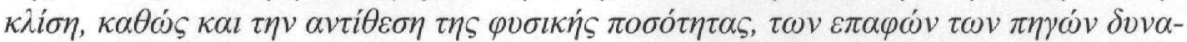

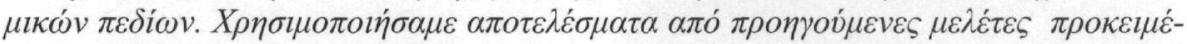

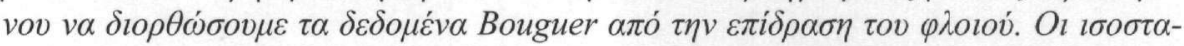

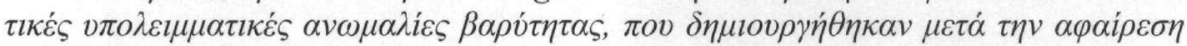

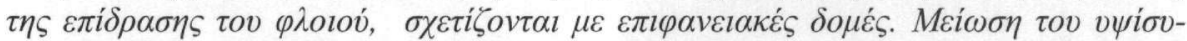

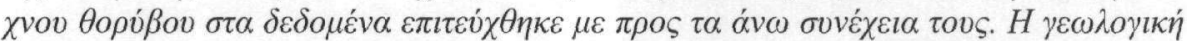

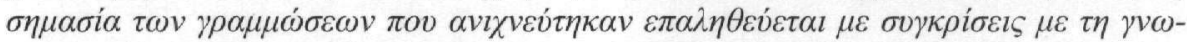

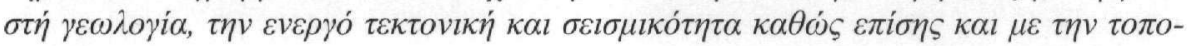

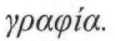

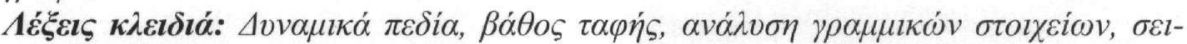

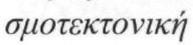




\section{Introduction}

The purpose of this study was to gain a better understanding on the tectonic structures of NE Greece from three-dimensional depth-to-source estimates using automated techniques on gridded potential-field data. Automated depth-to-source interpretation techniques available today rely on the fact that magnetic and gravitational fields are three-dimensional potential fields. The use of automated interpretation techniques is increasing, as faster computers and commercial software are now widely available (Reid et al. 1990). These automated techniques are capable of rapidly calculating depth estimates from large grids of data in order to get a general idea of the contact locations and depth. The three-dimensional automated depth-to-source interpretation techniques used in this study include the simple analytic signal (Nabighian 1984, Roest and Pilkington 1992), the horizontal gradient (Grauch and Cordell 1987), and the local wavenumber (Thurston and Smith 1997). These techniques were applied to gridded gravity and magnetic data over NE Greece.

These methods have several sources of difficulty. For the deep-fracture pattern, a lack of sufficient precision in positioning and field measurement or closely spaced gravity and aeromagnetic data, will mean that not all anomalies are detectable, and some lineaments, especially subtle ones, will be lost. If fractures or fault systems do not juxtapose rocks with contrasting density or magnetization, no anomaly will be detected, or a lithologic contact with no relative motion may coincide with a shallow lineament with no intervening penetrative fracture, thus giving a false correlation. For the shallow-fractures, lack of sufficiently precise data is a limitation, and some anthropogenic factors may lead to false identifications. Shallow burial by surface deposits may obscure fractures. If line spacing is large, short wavelength anomalies may also appear as aliased signals.

The potential-field manifestation of a fault may vary along its trend, depending on the local geology, so alignments of discontinuous multiple local anomalies are of interest. The results of the potential field studies are interpreted jointly with the seismological and other geological data.

\section{Geological setting}

The geological structure of the broader region of NE Greece consists of formations attributed mainly to the Rhodope massif and its surroundings, namely the Serbomacedonian massif to the west and the Circum-Rhodope belt to the east.

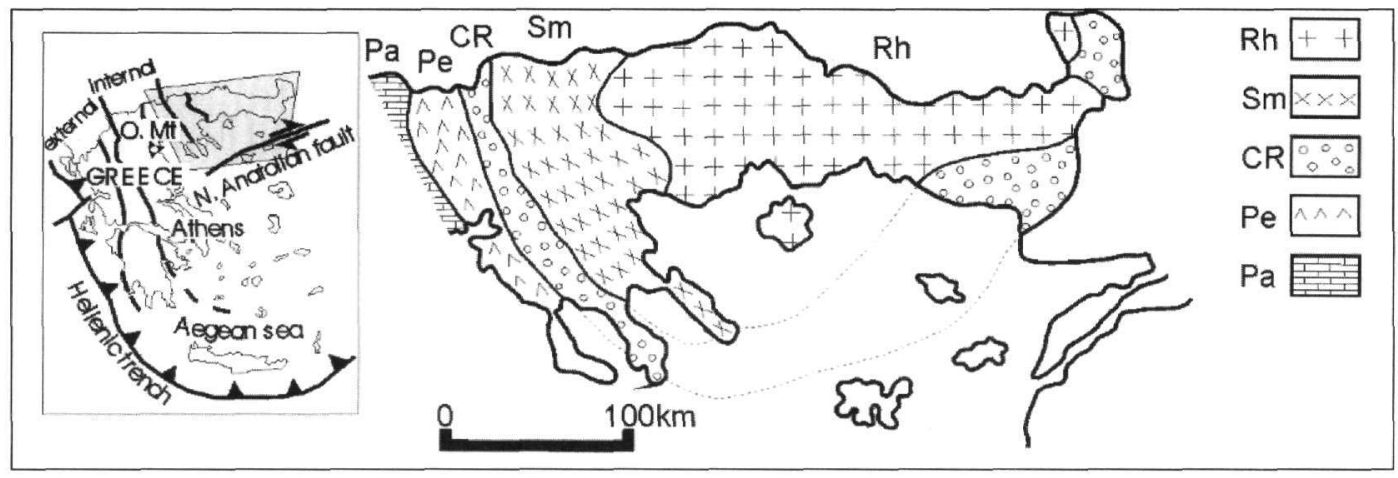

Figure 1 - Geological map of NE Greece (after Mountrakis 1985). The geological zones in this area are the Rhodope massif ( $\mathrm{Rh})$, the Serbomacedonian massif $(\mathrm{Sm})$, the Circum Rhodope belt (CR), and further to the west the Axios zones of Peonias (Pe) and Paiko (Pa)

The Rhodope massif consists of gneisses, marbles and mica schists of a thickness about $24 \mathrm{~km}$. Tertiary granitoids intruded the Rhodope metamorphic rocks at various times from Eocene to Miocene. The Greek Rhodope has been subdivided by Papanikolaou and Panagopoulos (1981) into an upper tectonic unit, that was called the Sidironero unit by Kilias and Mountrakis (1990) or 
the West Thracian gneiss complex by Dinter and Royden (1993), and a lower tectonic unit, that was called the Pangaio unit by Kilias and Mountrakis (1990) or the Rhodope metamorphic core complex by Dinter and Royden (1993). These units are separated by a long SE trending thrust zone that is dipping NE, from Xanthi to the SW Bulgaria (Papanikolaou and Panagopoulos 1981, Kilias and Mountrakis 1990).

The Serbomacedonian massif was diveded into two crystalline "series" by Kockel et al. (1971, 1977): an eastern one, the Kerdilia series, largely composed of migmatic gneisses, amphibolites and marble, and a western one, the Vertiscos series, composed of intercalations of schists, leucocratic and augen gneisses and amphibolites. From their tectonostratigraphic position the Kerdilia represents the lower unit and the Vertiskos the upper unit. Granitoid bodies intruded into the Serbomacedonian massif at various times from Jurassic to Oligocene.

The Circum-Rhodope belt in Thrace was divided by Papadopoulos (1982) into the Makri Unit and the Drymos-Melia Unit. The Makri Unit is further subdivided into two series: the Metasedimentary Series which comprises marble, dolomite, limestone, calc-schist, phyllite and metaconglomerate and the conformably overlying Greenschists Series which consists of greenschists, chloritic schist, talc schist, mica schist, seprentinite, gabbroic rocks, and quartzite. Metavolcanic and metapyroclastic rocks occur in the base of the Drymos-Melia Unit and are overlain conformably by flysch type post-sediments. Tertiary igneous rocks intruded the CircumRhodope rocks.

Following the Alpine orogen molassic sedimentation was initiated in the Paleogene, which was associated with graben formation and faulting. Thick molassic sediments were deposited in large basins during the Middle Hellenic orogenic belt (M/U Eocene - Oligocene) in the region behind the front of orogenesis or parallel to this one. Neogene and Quaternary sediments were deposited later in the Strymon, Drama, Xanthi-Komotini, Delta of Nestos, Orestiada, and Alexandroupolis basins. The basin of Strymon is a typical post-orogenic graben, which is still active. It has been formed between the Serbomacedonian massif on the west and the Rhodope massif on the east.

The wider area of the North Aegean is characterized by the presence of great neogene-quaternary basins, which follow the ENE-WSW, WNW-ESE and N-S (with deviations from NNW-SSE to NNE-SSW) directions of the most important faults of Eastern Macedonia and Thrace. The great fault zones determined through marine geophysical and geological surveys implemented over the North Aegean Sea region, during oil investigation projects, present also the same main directions.

\section{Seismotectonic setting}

The seismotectonic setting of the region studied here (Northern Aegean Sea and the surrounding lands) is mainly controlled by the intrusion of shearing from the east, due to the motion of the North Anatolian Fault (NAF), and the interaction with the back-arc Aegean extension.

The land regions of eastern Macedonia and Thrace (Fig. 2) have moderate size seismicity in the present century, however strong historical events did occur in these regions. On the contrary, the Northern Aegean Sea is the site of frequent and strong events, whose focal mechanisms (Fig. 2) show strike-slip faulting along mainly NE-SW trending planes. These shear motions are sometimes combined with strong normal components, indicating that the area is undergoing transtension (Kiratzi 2002).

The fast extension deformation rates (Papazachos and Kiratzi 1996) resulted in very thin crust in the North Aegean Trough. The NE-SW trending Sporades basin and the Saros Trough dominate in the bathymetry, and the faults bounding these basins, indicate strike-slip tectonics combined with normal faulting (Koukouvelas and Aydin 2002). The NW-SE trending basins, like the Orfanos Gulf and the Thermaikos Gulf, are mainly characterized by the occurrence of normal faulting events, along NW-SE trending planes and the T-axes trend approximately NE-SW, in accordance with the present day elongation of these basins. 


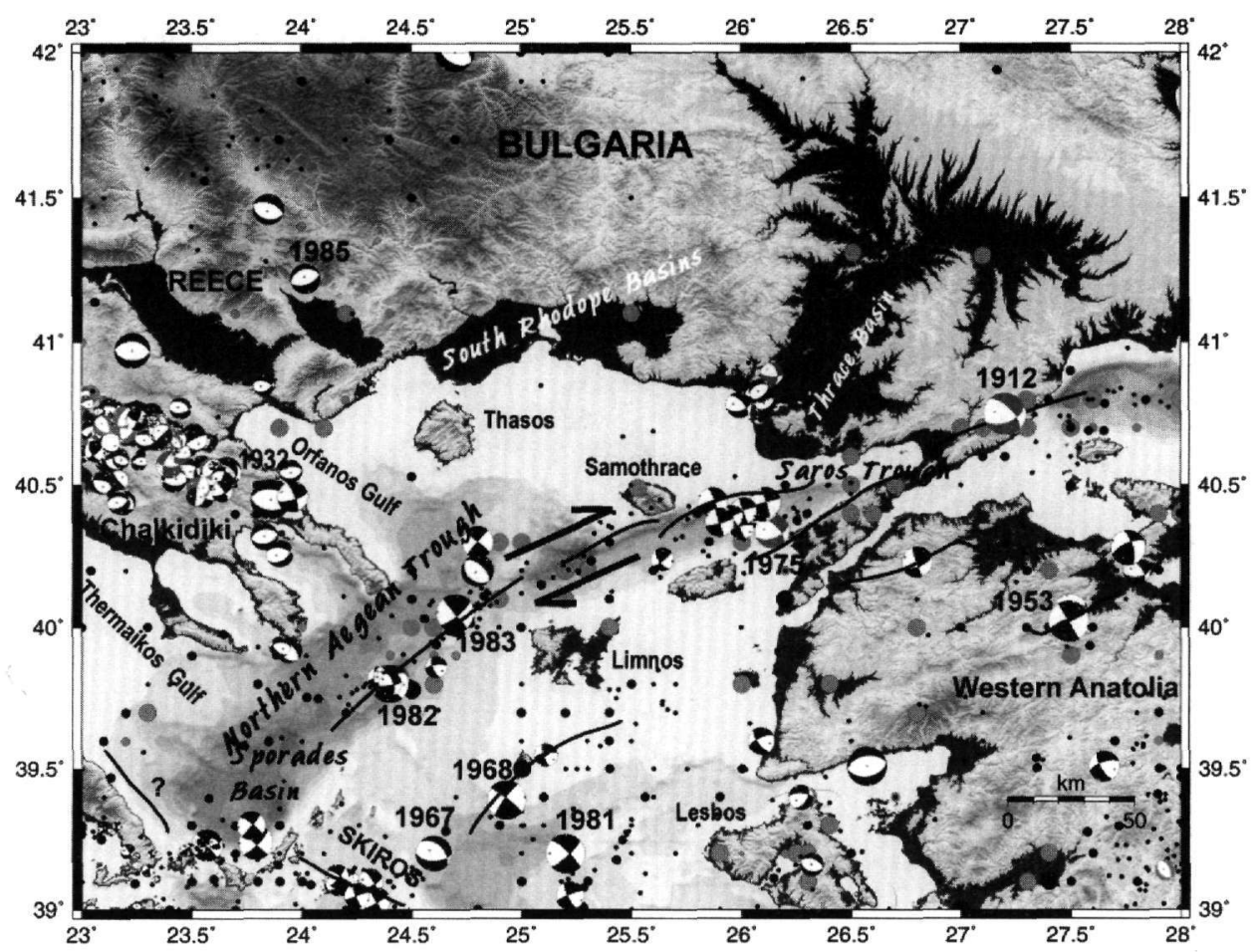

Figure 2 - Seismicity (pre-1911 events as grey circles, post-1911 black circles; scaled to magnitude) and focal mechanisms available for the region (from Kiratzi and Louvari 2003). Note the prevalence of shear motions along the Sporades and Saros Trough basins, which are sometimes combined with normal faulting. The NW-SE faults near Skiros island play significant role in the termination of the NE-SW trending shearing from the east. They also affect the way the motion is transferred in the $\sim \mathrm{E}-\mathrm{W}$ normal faulting system in central Greece

In brief, the interaction of the NE-SW shearing from the North Anatolian Fault with the $\sim \mathrm{N}-\mathrm{S}$ extension in the Aegean is now well accepted. Even though the question of the mode of propagation of the dextral shearing, imposed from the operation of the strands of the North Anatolian Fault that enter into the Aegean Sea, is not yet well defined, however most publications recognize that the NW-SE trending structures play an important role in the termination of the NAF zone. These structures are interpreted as normal faults with sinistral strike-slip motion from geological data (Koukouvelas and Aydin 2002) and the occurrence of the 1967 normal faulting earthquake, whereas recent seismic data (e.g. Skiros 2001 earthquake, Benetatos et al. 2002 and references therein) indicate the simultaneous operation of strike-slip faults, as well along NW-SE planes, with sinistral strike-slip motion.

\section{Geophysical data}

The available aeromagnetic data were from the survey of ABEM-Elektrisk Malmetning that was flown between June and October 1966, on behalf of IGME (Greek Institute of Geology and Mineral Prospection). Flight lines were flown at constant terrain clearance of $275 \pm 75 \mathrm{~m}$ above ground level, with a line spacing of $800 \mathrm{~m}$ and tie lines every $30 \mathrm{~km}$. The direction of the flights was WSW-ENE, perpendicular to the regional strike of Hellenides. A proton magnetometer, type Sud Aviation MP - 101, modified by ABEM, with sensing head mounted in stinger on the tail of an Aero Commander, type $680 \mathrm{E}$ aircraft was employed. The measured field was recorded on a recording unit having a chart speed of $10 \mathrm{~cm} / \mathrm{min}$, corresponding to a length scale of 1:50000 at an 
aircraft speed of $225 \mathrm{~km} / \mathrm{h}$, and was readable on the analogue profile with an accuracy within one gamma. The analogue aeromagnetic profile data were digitized and processed by Stampolidis (1999). The data were interpolated to a grid of $500 \mathrm{~m}$ cell size.

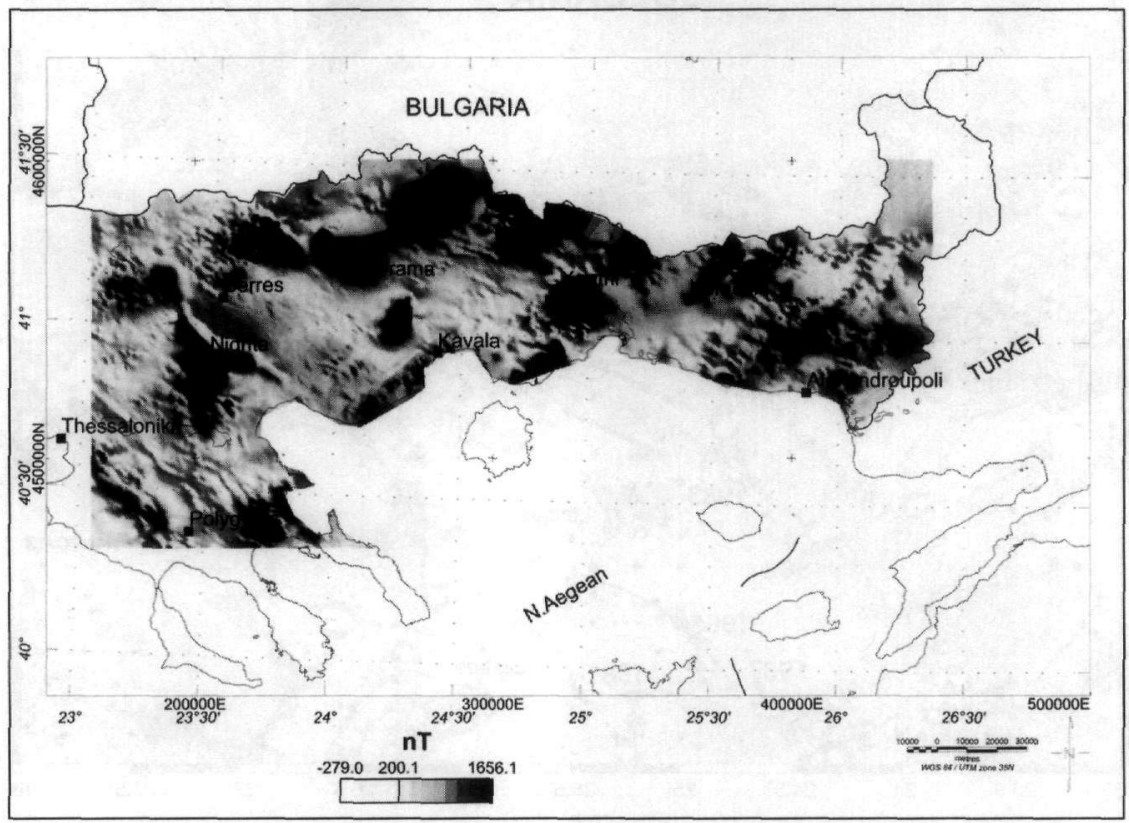

Figure 3 - Residual magnetic anomaly map of NE Greece

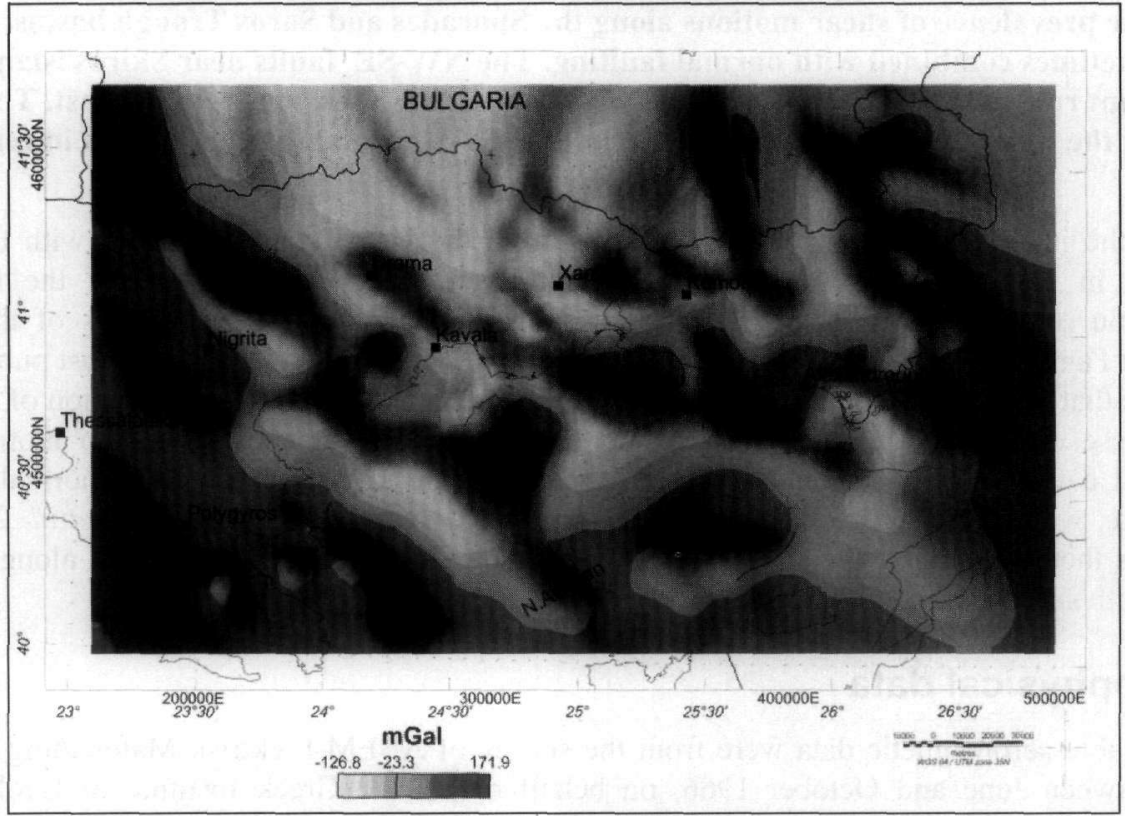

Figure 4 - Bouguer gravity map compiled from Lagios et al. (1994) data set. The cell size of the gravity grid was $\mathbf{4} \mathbf{k m}$. Data were extrapolated to form a full grid

Figure (3) shows the residual field anomaly map of Eastern Macedonia and Thrace, after the subtraction of IGRF. The aeromagnetic survey covered only the land of the Greek territory. 
The Bouguer anomaly data were extracted from the Greek gravity database that is available to the public (Lagios et al. 1994). The database contains the bouguer anomaly values which were measured in the nation wide campaign of Makris and Stavrou (1984). It is also complemented by data aquired in various industrial campaigns carried out by the IGME and the Public Petroleum Company (DEP-EKY). The offshore data were digitised from shipborne gravity maps.

Figure (4) shows the Bouguer gravity map compiled from this data set. The cell size of the gravity grid was $4 \mathrm{~km}$.

\section{Interpretation techniques}

The three-dimensional automated depth-to-source interpretation techniques are applied to gridded potential field data. The horizontal gradient method (Grauch and Cordell 1987) is the simplest approach to estimating gravity or magnetic contact locations and depths, because it does not require calculating vertical derivatives. The horizontal derivatives usually are computed in the space domain using splines.

The horizontal gradient magnitude peaks over magnetic or gravity contacts under certain assumptions (Grauch and Cordell 1987). In order to satisfy some of these assumptions for the magnetic contacts, it is necessary to apply a standard phase shift to the data known as reduction to the pole (RTP). It is also possible to assume very thin magnetic sources by using a pseudo-gravity transformation instead of a reduction to the pole. For the gravity contacts it is feasible to assume very thick gravity sources by using a pseudo-magnetic transformation instead of the gravity anomaly.

Nabighian (1972) introduced the simple analytic signal in the geophysical literature. Analytic signal employs the vertical and horizontal derivatives of the total field to estimate the source body location and depth. The simple analytic signal or "energy envelope" of a three-dimensional magnetic or gravity anomaly could be computed easily utilising the potential-field geophysical software provided by the U.S. Geological Survey (Phillips 1997). The horizontal derivatives usually are computed in the space domain using splines, and the vertical derivative is computed in the wavenumber domain using fast Fourier transforms. The amplitude of the simple analytic signal in three dimensions is an "envelope" of all possible phase shifts of an observed magnetic anomaly and peaks over them (Roest et al. 1992). The analytic signal function is independent of the regional magnetic field direction, the source magnetization and the dip of the contact (Roest et al. 1992). The magnetic or gravity contacts must be isolated and effectively two-dimensional.

Roest et al. (1992) gave an expression of the local phase of the simple analytic signal in three dimensions. The local wavenumber method comes from The Source Parameter Imaging (SPI) method (Thurston and Smith 1997), which extends the theory of the simple analytic signal by computing three complex attributes from which source parameters of magnetic contacts could be calculated. In the case of spatial magnetic data, these attributes include the local amplitude (analogous to the analytic signal amplitude), local phase and local wavenumber. The local wavenumber $\mathrm{k}$ is defined as the rate of change of the local phase $\Theta$ of the total field $\mathrm{T}$ with respect to the horizontal ( $\mathrm{x}$ and $\mathrm{y}$ ) directions (Thurston and Smith 1997).

Higher order derivatives are calculated in the frequency domain. The local wavenumber method, like the analytic signal, peaks over magnetic contacts and is independent of the regional magnetic field direction, the source magnetization and the dip of the contact (Thurston and Smith 1997). Phillips (1997) suggested that taking the vertical integral of the total magnetic field before calculating the local wavenumber would improve depth results for contacts with a finite thickness.

The local wavenumber method is usually applied to magnetic data while gravity data have to be transformed to equivalent magnetic data using the pseudomagnetic transformation. 


\section{Data processing}

\subsection{Gravity data}

Regional/residual separation was the first step in our gravity data processing layout. Tsokas and Hansen (1997) calculated the gravity effect of the crust in Greece. The residual gravity map was created from the subtraction of the crust field from the complete Bouguer anomaly map. This map is in fact the isostatic residual map. The residual gravity field is characterized by local anomalies caused by relative shallow features in the region, which mainly reflect the geological and tectonic structure of the area.

Complex attributes analysis requires higher order derivatives. An accurate calculation of higher order derivatives is often difficult when data contain noise. Following Phillips (2000) we upward continued the data in the frequency domain by one grid cell (i.e. $4 \mathrm{~km}$ ) to reduce noise, prior to any other processing. We used this upward continued field as common input for all three interpretation methods.

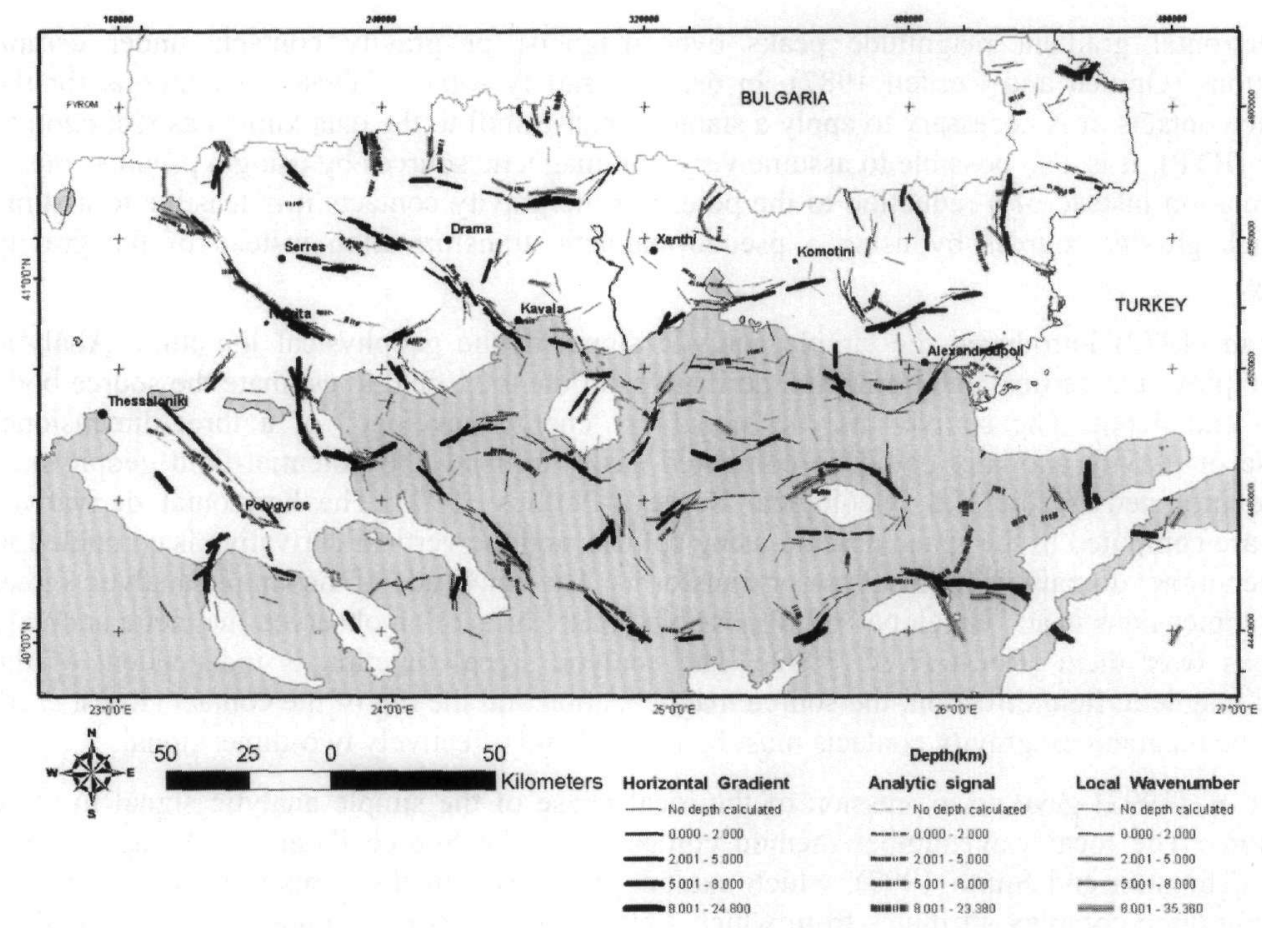

Figure 5 - Contact location and depth estimates for Bouguer gravity data. Only depth estimates with errors less than $\mathbf{2 0} \%$ were retained for plotting. Estimates with errors between $20-50 \%$ are shown with thin lines. Source depth estimates are proportional to line thickness, as shown in legend

All the processing procedures were performed using potential-field geophysical software provided by the U.S. Geological Survey (Philips 1997). Location of gravity contacts and their depths estimates using the horizontal gradient magnitude were calculated using HDEP (Phillips 1997). A depth-error threshold of $\leq 50 \%$ was used for the location of contacts, while a threshold of $\leq 20 \%$ was used for the depths. Location of contacts and depth estimates using the simple analytic signal amplitude were calculated using ASDEP (Phillips 1997). This program uses a similar procedure as HDEP and has the same output. The same depth-error thresholds were used. The same approach was used for depth calculations using the local wavenumber. Following Tsokas (2000), Gettings and Houser (2000) and Stampolidis et al. (2005) we applied the local wavenumber method directly 
on the gravity field. The program LOCDEP (Phillips 1997) was used, and a depth-error threshold of $\leq 50 \%$ for the contact locations, and a threshold of $\leq 20 \%$ for the depths were also used.

Output from ASDEP, HDEP and LOCDEP includes $x$ and $y$ locations, calculated depths, calculated depth errors and strikes, while output from LOCDEP also include the dip vector. These outputs were imported into an OASISmontaj database. Strike and dip data were converted into vector information for the purpose of plotting. The strike vector information was used to plot headless arrows on a map with their centers at the calculated locations. The headless arrows were used to display the calculated strikes appropriately. All preserved depth solutions were then plotted in plan view, using graduated symbols. The dip vector information of the LOCDEP method can be used to plot headed arrows on a map with their ends at the calculated locations that were proportional in size to the dip angles.

Figure (5) contents the outputs of the three methods applied to gravity data. The crude depths estimates for contact locations are shown with colored vectors for the accepted error threshold and with black vector for those solution having larger errors. These vectors are plotted with their centers at the contact location and angles equal to the strike.

\subsection{Magnetic data}

The aeromagnetic data were collected at a nominal flight altitude of $275 \mathrm{~m}$ above the topography. In order to remove the high frequency noise component from the data we upward continued them by one grid cell (i.e. $500 \mathrm{~m}$ ). The derived continued data grid was the input for the following depth-to-source analysis. The same programs, namely ASDEP, HDEP and LOCDEP, where used in a processing procedure similar to that applied to gravity data.

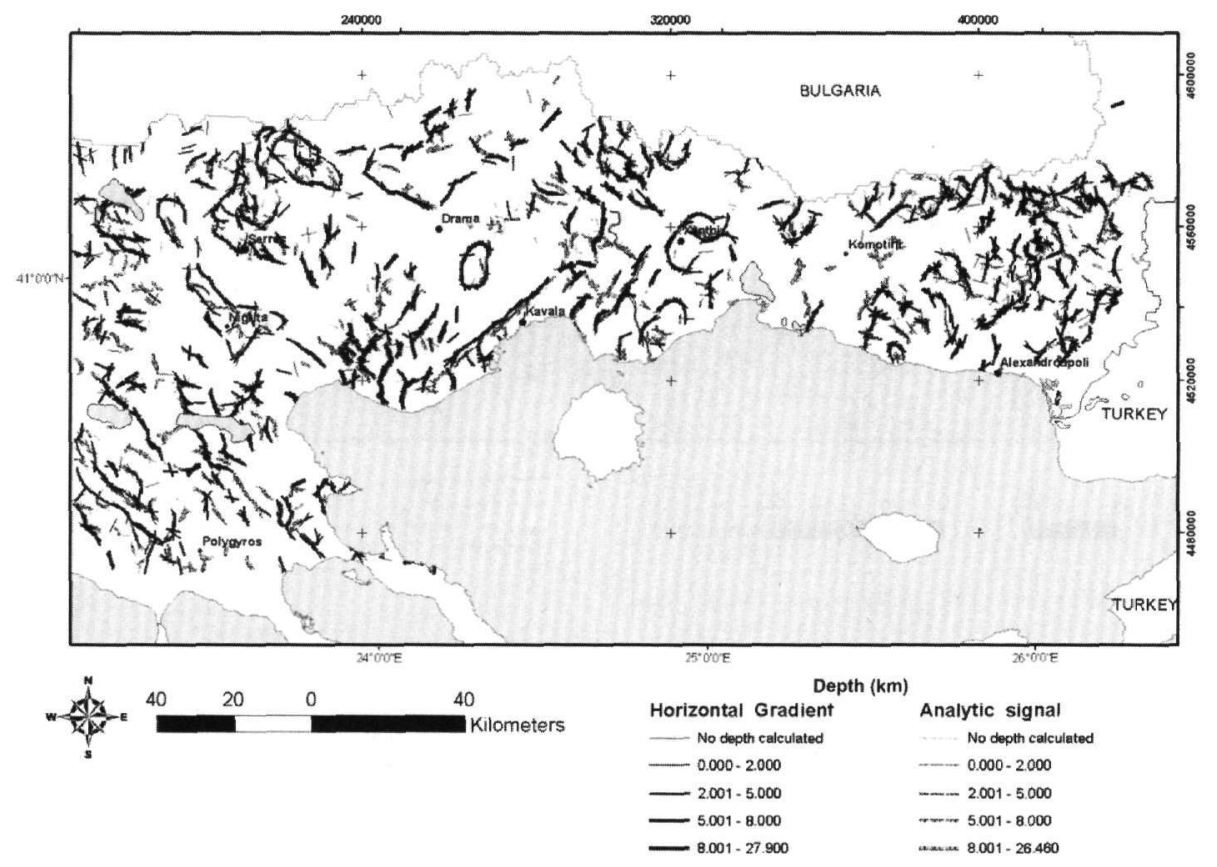

Figure 6 - Depth estimates for magnetic data from the Horizontal Gradient and the Analytical Signal methods. Only depth estimates with errors less than $20 \%$ were retained for plotting. Estimates with errors between 20-50\% are shown with thin lines. Source depth estimates are proportional to line thickness, as shown in legend

The horizontal gradient method was applied to the pseudo-gravity field, where the computed depth estimates represent maximum depths with the assumption of thin sources. The analytic signal 
method uses the square of the analytic signal amplitude. We applied the method to the first vertical integral of the magnetic field. The method generally produces good horizontal locations for contacts and sheet sources regardless of their geologic dip or the geomagnetic latitude. The estimated depths are accurate for sheet sources (Phillips 2000). Dipolar effects are absent. The transformations used as input in the previous methods generally act as low pass filter, thus producing a smaller number of possible contact location solutions (Fig. 6). The local wavenumber method was applied to the upward continued magnetic field. The estimated contacts are more than the other methods. A depth-error threshold of $\leq 50 \%$ for the contact locations, and a threshold of $\leq 20 \%$ for the depths were used for all the three methods.

\section{Discussion and Conclusions}

We have used three-dimensional depth-to-source interpretation techniques on the gravity and magnetic data of NE Greece, in order to infer the characteristics of the major tectonic features. In Figs 7 and 8 we combine the tectonic lineaments as inferred from the gravity and magnetic data, respectively with the tectonic data inferred from regional geology as well as the seismicity data.

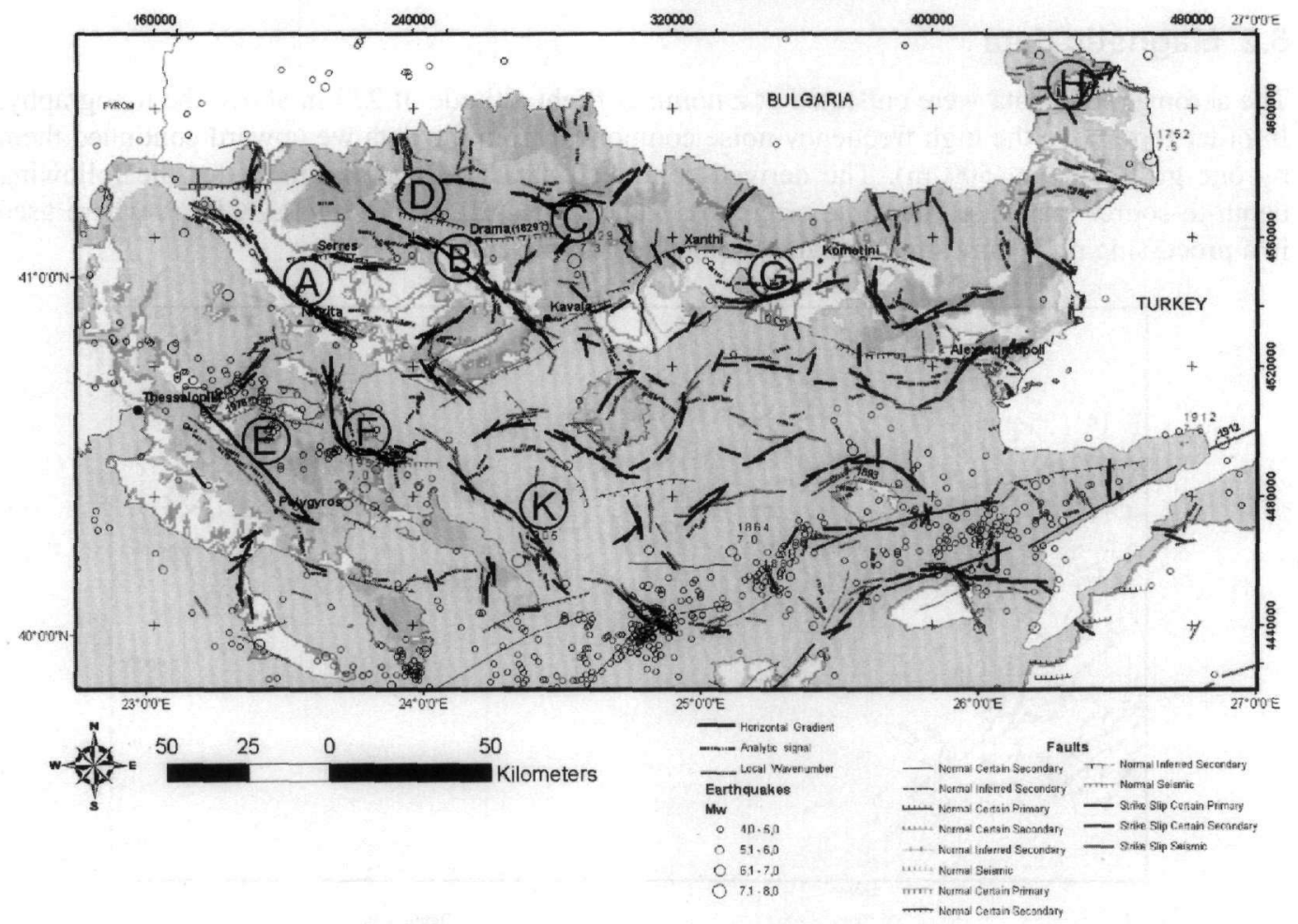

Figure 7: Tectonic lineaments as inferred from the gravity data plotted with the tectonic data, the regional geology and the seismological data. Letters are explained in the text.

It is evident that the distribution of the local estimates coincides fairly well with large scale geologic structures, namely the borders of the major geological zones. They show the general NW - SE trend in central and eastern Macedonia region. This fact implies that the zones have discernible mean densities, a fact that was more or less expected. Thus, their boundaries comprise geophysical contacts. In this respect, the technique of complex attributes recognizes them and yields their quantitative characteristics (burial depth, strike and dip).

In this context, besides the expected agreement between the geophysical estimates and the visible contacts of the zones, the results should be considered as very reliable for the cases where these 
contacts are concealed under sedimentary cover. The lineament running parallel to the Strymon basin, indicated by the letter $\mathrm{A}$ in figure 7 is such an example. The westernmost end of this passes in particular passes through the city of Nigrita. It should reflect the concealed western border of the Strymon basin which was also detected by reflection seismics (Hellenic Petroleum Company personal communication) and former geophysical and geothermal investigation (Arvanitis 2003). A lineament parallel to the one discussed before starts just southwestwards of Kavala and continues in an approximately NNW direction till the Bulgarian borders (B in Fig. 7) Its southeastern part (near Drama and Kavala) coincides well with a normal fault mapped by Kilias et al. (1999). However, the fault where probably a major shock $(M=7.3)$ occurred in 1829 does not produce any signature on the estimates inferred by the study of the potential fields. This fractured (C in Fig. 7) is shown to cross the city of Drama having an E-W direction. Similarly, no estimate is yielded for the fault which is close to the previous one but with a WNW-ESE direction (D in Fig. 7).

A major lineament is observed ( $\mathrm{E}$ in Fig. 7) which runs from Langadas lake to the area of Polygyros in Chalkidiki. This is the expression of the border between the Circum Rhodope belt and the Serbomacedonian massif.

The fault of the $M=7.0$ earthquake of 1932 in Ierissos gulf seem to correlate well with the lineament inferred by the gravity data ( $\mathrm{F}$ in Fig. 7). Further, the lineament bends towards North and extends in this direction further northeast from the lake Volvi.

The Kavala-Xanthi-Komotini fault is mapped in detail by surface observations as shown in figure 7. Clearly this major tectonic feature is not expressed in the estimates yielded from gravity data. On the contrary, a lineament is observed south of the Porto Lago laggon (G in Fig. 7). This is an area covered by sediments, therefore the inferred lineament reflects a tectonic feature of the basement that has no surface expression.

Many other lineaments are observed in the prefecture of Komotini and Evros. It is worth noting that the visible part of the fault associated with the $M=7.5$ shock of 1752 ( $\mathrm{H}$ in Fig. 7 ) is coincident with a number of fractures none of them having the same orientation as the fault.

Also linemeants are observed offshore and around the island of Thassos in particular. The surface expression of the fault attributed to the 1893 earthquake is visible at the northern shores of Samothraki. Its nearest lineament obtained by the gravity data $8 \mathrm{~km}$ to the north and appears concave. If this feature is associated to the 1893 earthquake, then the fault on the shores of Samothraki is probably a secondary effect.

The lineament that correlates well with a known branch of the Anatolian fault is marked as $(\mathrm{J})$ in figure 7. The lineament offshore northwestwards of mount Athos ( $\mathrm{K}$ in Fig. 7) seems to be a length one. It is probably associated with the $M=7.5$ earthquake of 1905 .

The maxima of the horizontal gradient and the estimates inferred from the complex attibutes of the total magnetic field delineate the edges of buried bodies. In this respect the Vrontou (A in Fig. 8), the Philippi (B in Fig. 8) and the Xanthi (C in Fig. 8) granites are very well picked up. Stampolidis et al. (2000) and Tsokas et al. (1996) studied respectively the Philippi and Xanthi granites and produces $3 \mathrm{D}$ models. The outlines of these intrusions are in agreement with the results of these studies. Similarly, the northern edge of the Kavala granite is very well depicted by the relevant lineament marked as D in figure 8 .

The general alignment of the estimated lineaments in the Central Macedonia is in the NW-SE direction, parallel to the Hellinides (see E in Fig. 8). There are some lineaments observed at the eastern end of the Kavala-Komotini fault ( $\mathrm{F}$ in Fig. 8) that exhibit similar alignment to the fault. Several other features seen in figure 8 need further investigations. They are mainly of local interest and thus a detailed discussion on them will lead the present paper pretty far away. Our main aim is 
to detect the major features and to try to correlate them with visible major fractures and the probable traces of big earthquakes.

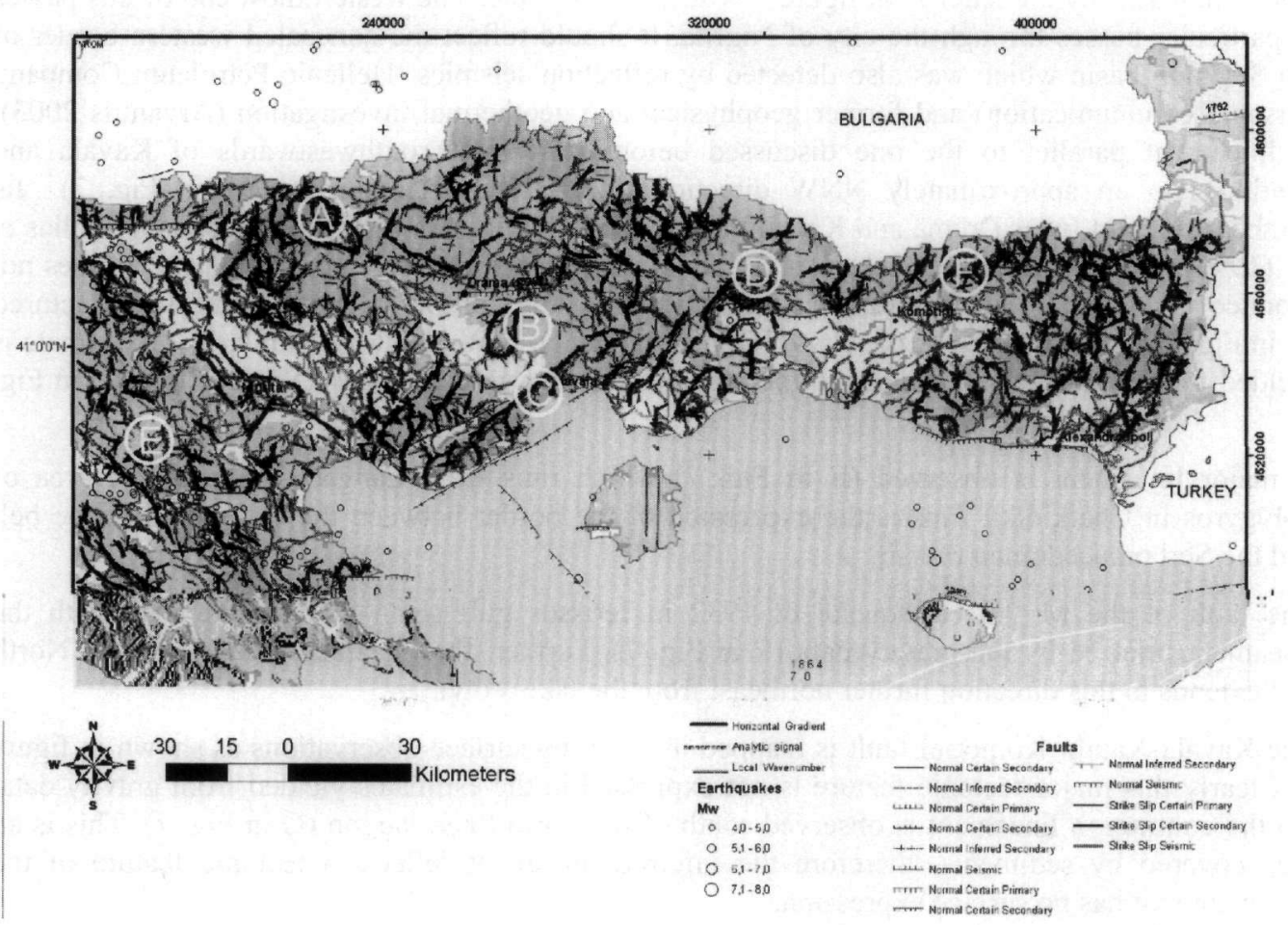

Figure 8 - Tectonic lineaments as inferred from the magnetic data plotted with the tectonic data, the regional geology and the seismological data. Letters are explained in the text

\section{Acknowledgments}

This work was financially supported by the Ministry of National Education and Religious Affairs of Greece and the European Regional Development Fund (Projects Pythagoras II and INTERREG IIIA).

\section{References}

Arvanitis, A., 2003. Geothermalinvestigations on the SW part of Strymon basin, PhD thesis, Univ. of Thessaloniki, 479pp.

Benetatos, C., Roumelioti, Z., Kiratzi, A., and Melis, N., 2002. Source parameters of the M 6.5 Skyros island (North Aegean Sea) earthquake of July 26, 2001, Ann. Geophys., 45, 513526.

Dinter, D.A., and Royden, L., 1993. Late Cenozoic extension in northeastern Greece: Strymon Valley detachment system and Rhodope metamorphic core complex, Geology, 21, 45-48.

Gettings, M.E., and Houser, B.B., 2000. Depth to bedrock in the Upper San Pedro Valley, Cochise County, southeastern Arizona, Open-File Report 00-138, Online version 1.0. (http://pubs.usgs.gov/of/2000/of00-138/)

Grauch, V.J.S., and Cordell, Lindrith, 1987. Limitations on determining density or magnetic boundaries from the horizontal gradient of gravity or pseudogravity data, Geophysics, 52(1), 118-121. 
Kilias, A., and Mountrakis, D., 1990. Kinematics of the crystalline sequences in the western Rhodope massif, Geol Rhodope, 2,100-116.

Kilias, A., Falalakis, G., and Mountrakis, D., 1999. Cretaceous-Tertiary structures and kinematics of the Serbomacedonian metamorphic rocks and their relation to the exhumation of the Hellenic Hinterland (Macedonia, Greece), International Journal of Earth Sciences, 88, 513-531.

Kiratzi, A., and Louvari, E., 2003. Focal mechanisms of shallow earthquakes in the Aegean Sea and the surrounding lands determined by waveform modeling: a new database, Journal of Geodynamics, 36, 251 - 274.

Kiratzi, A., 2002. Stress tensor inversions along the westernmost north and central Aegean Sea, Geophys. J. Int., 106, 433-490.

Kockel, F., Mollat, H., and Walther, H., 1971. Geologie des Serbomazedonischen Massivs und seines mesozoischen Rahmes (Nordgrienchenland), Geol Jahrb, 89, 529-551.

Kockel, F., Mollat, H., and Walther, H., 1977. Erläuterungen zur geologischen Karte der Chalkidhiki und angrenzender Gebiete, 1:100,000 (Nord-Griechenland), Bundesanstalt fur Geowisseschaften und Rohstoffe, Hannover, 119pp.

.Koukouvelas, I., and Aydin, A., 2002. Fault structure and related basins of the North Aegean Sea and its surroundings, Tectonics, 21(5), 1046, doi:10.1029/2001TC901037.

Lagios, E., Chailas, S., Hipkin, R. G., and Drakopoulos, J., 1994. Gravity and Topographic Data Banks of Greece: University of Athens, Athens.

Makris, J., and Stavrou, A., 1984. Compilation of gravity maps of Greece. Hamburg University, Institute of Geophysics, Hamburg, 12pp.

Nabighian, M.N., 1972. The Analytic Signal of Two-Dimensional Bodies With Polygonal CrossSection: Its Properties And Use For Automated Anomaly Interpretation, Geophysics, 37, 507-517.

Nabighian, M.N., 1984. Toward A Three-Dimensional Automatic Interpretation of Potential-Field Data via Generalized Hilbert Transforms: Fundamental Relations, Geophysics, 49, 780786.

Papadopoulos, P., 1982. Geological map of Greece; Maronia sheet, scale 1 :50,000. IGME, Athens.

Papanikolaou, D, and Panagopoulos, A., 1981. On the structural style of southern Rhodope, Greece, Geol Balc, 11, 13-22.

Papazachos, B.C., Comninakis, P.E., Scordilis, E.M., Karakaisis, G.F., and Papazachos, C., 2006. A catalogue of earthquakes in the Mediterranean and surrounding area for the period 19012005, Publication of the Dept of Geophysics, University of Thessaloniki.

Papazachos, C.B., and Kiratzi, A.A., 1996. A detailed study of active crustal in the Aegean and surrounding region, 1996, Tectonophysics, 253, 129-153.

Phillips, J.D., 1997. Potential-Field Geophysical Software for The Pc, Version 2.2. U.S. Geological Survey Open-File Report 97-725.

Phillips, J.D., 2000. Locating magnetic contacts: a comparison of the horizontal gradient, analytic signal, and local wavenumber methods: Society of Exploration Geophysicists, Expanded Abstracts with Biographies, 2000 Technical Program, v.1, 402-405pp.

Reid, J.M., Allsop, J.M., Granser, A.J., and Somerton, I.W., 1990. Magnetic interpretation in three dimensions using Euler deconvolution, Geophysics, 55, 80-91. 
Roest, W. R., Verhoef, J., and Pilkington, M., 1992. Magnetic interpretation using the 3-D analytic signal, Geophysics 57(1), 116-125.

Stampolidis, A., 1999. The magnetic field of Macedonia and Thrace and its relation to the geological and geophysical structure of the area, Doctorate thesis, Aristotle University of Thessaloniki.

Stampolidis, A., Tsokas, G.N., Elefteriadis, G., and Kondopoulou, D., 2000. Investigation of potential fields anomalies related with the Philippi basin and granitoid intrusion, NE Greece, Journal of the Balkan Geophysical Society, 3(4), 59-66.

Stampolidis, A., Tsokas, G.N., and Kiratzi, A., submitted, 2005. Seismotectonics Of Western Greece Using Geophysical And Seismological Data, Frontiers in Earth Sciences, Special Volume, Springer-Verlag series.

Thurston, J.B., and Smith, R.S., 1997. Automatic Conversion of Magnetic Data to Depth, Dip, and Susceptibility Contrast Using Spi TM Method, Geophysics, 62 (3), 8-7-813.

Tsokas, G.N., 2000. The Milos Island Bouguer anomaly revisited by means of a complex attribute analysis and inferred source parameter estimates, Journal of the Balkan Geophysical Society, 3(4), 77-86.

Tsokas, G.N., Christofides, G.C., and Papakonstantinou, C., 1996. A Geophysical Study of the Granites and the Sedimentary Basins of the Xanthi Area (N.Greece), PAGEOPH, 146, 2, 365392.

Tsokas, G.N., and Hansen, R., 1997. Study of the crustal thickness and subducting lithosphere in Greece from gravity data, Journal of Geophysical Research, 102, 20585-20597. 